\title{
INTUITION IN CLINICAL DECISION-MAKING BY THE NURSE IN ICU
}

\section{Eben Arries}

RICN, MCur (Lecturer)

Rand Afrikaans University

\author{
Annatjie Botes \\ DCur, MA (Philosophy) (Professor) \\ Rand Afrikaans University
}

\author{
Elsabe Nel \\ DCur, RICN (Senior Lecturer) \\ Rand Afrikaans University
}

\begin{abstract}
This research article follows on a previous article where the results of a concept analysis of intuition were reported. The purpose of this article is to debate the role of intuition in clinical decision-making by the nurse in ICU. Clinical decision-making has been noted by many critical care nurses and nurse researchers as one of the most critical elements of critical care nursing. Minute by minute, the critical care nurse is bombarded with a vast array of data that is, in part, derived from numerous monitoring devices employed in modern ICUs. Although interpretation of the data begins with an understanding of the physiology or pathophysiology being monitored, the ultimate application of the monitoring of this data depends on the ability of the critical care nurse to make clinical decisions.
\end{abstract}

Clinical decision-making refers to a reasoning process that the critical care nurse employs in order to care for the critically ill patient. The purpose of clinical decision-making in ICU is to promote the health of the critically ill patient through more complete and effective problem solving. Based on experience and observation of decision-making in ICU, it was observed that nurses in critical care units make clinical decisions, some of which they can justify, and others that they cannot justify. The latter type of clinical decision-making is sometimes referred to by nurses in critical care units as "gut-feeling" or intuition. Furthermore, it appears from this observation that clinical decision-making based on intuition is effective and contributes to better and more complete problem solving in critical care units. Therefore, the following question arises:

What is the role of intuition in clinical decision-making by the nurse in ICU?

From the debate on the role of intuition in clinical decision-making in ICU, the conclusion is drawn that in order to facilitate better and more complete problem solving in ICU, both clinical decisionmaking based on the nursing process and intuition are necessary.

\section{OPSOMMING}

Hierdie artikel volg op 'n vorige een waarin die resultate van ' $n$ konsepanalise van intuïsie beskryf is. Die 
doel van hierdie artikel is om die rol van intuïsie in kliniese besluitneming deur die verpleegkundige in die kritiekesorgeenheid te beskryf. Kliniese besluitneming word deur sommige kritiekesorgverpleegkundiges en verpleegnavorsers as ' $n$ kritiese element van kritiekesorgverpleging beskou. Die verpleegkundige in die kritiekesorgeenheid word op ' $n$ minuut-tot-minuut basis met 'n magdom data, wat deur middel van talle moniteringsapparaat bekom word, gebombardeer. Alhoewel die interpretasie van die data begin met ' $n$ begrip van die fisiologie of patofisiologie wat gemonitor word, hang die uiteindelike toepassing van die monitering van hierdie data af van die vermoë van die verpleegkundige in die kritiekesorgeenheid om kliniese besluite te neem.

Kliniese besluitneming dui op 'n denkproses wat deur die verpleegkundige in die kritiekesorgeenheid ingespan word om die kritieksieke pasiënt te verpleeg. Die doel van kliniese besluitneming in die kritiekesorgeenheid is om die gesondheid van die kritieksieke pasiënt deur middel van effektiewe en meer volledige probleemoplossing te bevorder. Vanuit ervaring en waarneming t.o.v. besluitneming in kritieksorgeenhede, is daar waargeneem dat die verpleegkundiges in kritiekesorgeenhede sommige kliniese besluite neem wat hulle kan verantwoord, en ander besluite neem wat hulle nie kan verantwoord nie. Laasgenoemde besluite word dikwels deur verpleegkundiges in kritiekesorgeenhede na "gut-feeling" of intuïsie verwys. Dit blyk verder uit die waarneming dat kliniese besluite op grond van intuïsie effektief is, en bydra tot beter en meer volledige probleemoplossing in kritiekesorgeenhede. Die vraag kan dus gevra word:

Wat is die rol van intü̈sie in kliniese besluitneming deur die verpleegkundige in die kritiekesorgeenheid?

Die gevolgtrekking waartoe daar vanuit die debat oor die rol van intuïsie in kliniese besluitneming in die kritiekesorgeenheid gekom is, is dat beide kliniese besluitneming op grond van die verpleegproses en intuïsie nodig is ten einde beter en meer volledige probleemoplossing in kritiekesorgeenhede te fasiliteer.

\section{INTRODUCTION AND PROBLEM STATEMENT}

This article follows on a previous article entitled "Concept analysis of intuition"(Arries, Botes \& Nel, 1999:88-99). The purpose of this article is to debate the role of intuition in clinical decisionmaking by the nurse in ICU.

Intuition is defined as a goal-directed, holistic, synthetical-analogical rather than an analytical process, whereby the critical care nurse interprets or makes decisions derived from incomplete data, in uncertain situations, with the goal of solving problems based on knowledge, experience and empathy. Because of the speed at which intuition occurs, the nurse is unable to justify his/her decisions or interpretations at that moment. Only after the problem is solved the nurse is, by means of reflection, able to justify his/her interpretations or decisions based on intuition (Arries, Botes \&
Nel, 1998:54). Minute by minute the critical care nurse is bombarded with a vast array of data that is, in part, derived from a multitude of monitoring devices employed in modern ICUs. Although interpretation begins with an understanding of the physiology or pathophysiology being monitored, the ultimate application of the data monitored depends on the ability of the critical care nurse to make clinical decisions.

Clinical decision-making refers to a reasoning process that the ICU nurse employs in order to care for the critically ill patient. The purpose of clinical decision-making is to promote the health of the critically ill patient, through the identification of health needs/problems and by implementing nursing actions in order to solve these problems (Baker, 1997:41). Because the patient in ICU is critically ill, these decisions must sometimes be made within a limited time frame accompanied with a great deal of uncertainty. Uncertainty may occur 
as insufficient empirically observable data is available or because the interaction between the data, social and psychological processes within the individual and the clinical decision-making context is poorly understood.

In order to understand clinical decision-making in ICU, I want to provide the reader with a narrative description of clinical decision-making occurring in ICU.

Mrs Brown, a thirty-year old woman, living in Johannesburg, was admitted to ICU because of an acute asthmatic attack. On admission, Nurse Oliver assessed the health status of the patient and gathered the following data:

- Heart rate of 160 beats per minute;

- Blood pressure of $80 / 50 \mathrm{mmHg}$;

- Increased work of breathing as reflected in a respiratory rate of 40 breaths per minute, accompanied with dyspnoea and the patient using extra-accessory muscles to breath;

- Temperature of $36.8^{\circ} \mathrm{C}$; and

- Peripheral saturation of $82 \%$ on oxygen that is administered via a $40 \%$ face-mask at 12 litres flow.

By means of auscultation of the patient's air entry, Nurse Oliver noted decreased air entry on the left lower lobe side of Mrs Brown's chest and some wheezing, indicating bronchospasm. Based on this data, Nurse Oliver diagnosed spontaneous pneumothorax. After notifying Dr Blom, the medical officer on duty in ICU at the time, she prepared for the insertion of an intercostal drain.

After an intercostal drain had been inserted by $\mathrm{Dr}$ Blom, Nurse Oliver, with the permission of Dr Blom, administered a bolus of Haemaccel intravenously to the patient. After the administration of this bolus of fluid, blood pressure increased to $100 / 60 \mathrm{mmHg}$ and the pulse rate decreased slightly to 155 beats per minute.
Bronchodilators, in the form of Berotec and Atrovent, were administered to the patient via a nebuliser in the hope of alleviating the bronchospasms. An arterial blood gas obtained from the patient after 30 minutes of insertion of the intercostal drain revealed the following: $\mathrm{pH}$ of 7.25 , Pao 2 of $55 \mathrm{mmHg}$, Paco 2 of $50 \mathrm{mmHg}$, base excess of $2,8 \mathrm{mmol} / \mathrm{L}$, bicarbonate $(\mathrm{HCO} 3)$ of $24 \mathrm{mmol} / \mathrm{L}$ and AaDpo 2 of 30 and an oxygen saturation of $82 \%$. Based on persistent increased work of breathing accompanied by the use of extraaccessory muscles by the patient in order to commence normal respiration, an inability of the patient to complete a full sentence, together with the results of an arterial blood gas, Nurse Oliver recommended to Dr Blom that the patient needed to be intubated and mechanically ventilated. Nurse Oliver assisted Dr Blom with the intubation of the patient and, based on the patient's weight and vital data, she selected the parameters to initiate mechanical ventilation. To ensure correct placement of the endotracheal tube, she checked for equal air entry on both lung fields and confirmed this with a chest X-ray.

A few minutes later Mrs Brown was mechanically fully ventilated in the controlled mode, as Dr Blom and Nurse Oliver wanted to control the peak alveolar pressures of the patient that were above $40 \mathrm{cmH} 20$. A positive inspiratory pressure of 35 $\mathrm{cmH} 20$ was selected to achieve adequate control of intrapulmonary pressures, a rate of 10 breaths per minute with an inspiratory:expiratory ratio (I:E ratio) of 1:2. Nurse Oliver knew from her studies in critical care nursing that the goal of ventilating patients with acute attacks of asthma is to maintain good oxygenation and limit intra-pulmonary pressures. She therefore selected an Fio2 of 1,0, and, as she knew that patients with acute asthmatic attacks develop an auto-PEEP (positive endinspiratory pressure) because of air-trapping in the lungs, she decided against dialling in an applied PEEP (positive end-expiratory pressure). To accomplish these goals in Mrs Brown, Nurse Oliver 
administered a sedative in the form of Midazolam, prescribed by the doctor to the patient, in order to calm her down and facilitate synchronisation between the patient and the ventilator.

Mrs Brown remained hemodynamically unstable with numerous monitoring devices attached to her body, for example, a cardiac monitor, a ventilator, an oxygen saturation monitor and a baumanometer to objectively measure her vital data. Catheters, for instance, a Foley's urinary catheter, an internal jugular central venous catheter, a radial arterial catheter to measure a series of arterial blood gases, and serum electrolytes were attached to Mrs Brown. Nurse Oliver assessed the health status of Mrs Brown hourly, using data that she obtained from the various monitoring devices and catheters that were attached to the body of the patient. Based on this data, she identified problems and made further diagnoses, intervening with the necessary actions based on her knowledge of critical care nursing, in order to prevent deterioration of the health status of the patient.

Five days after the initial insult on the health status of Mrs Brown, there was a dramatic improvement in her physical condition. So much so, that the mode of ventilation was weaned to the assisted mode of ventilation, using synchronised intermittent mandatory ventilation with pressure support, to augment the spontaneous respiratory efforts of the patient. The ventilator parameters were as follows: Fio2 of 0,30, pressure support of $10 \mathrm{cmH} 20$ above the level of applied PEEP, a PEEP of $5 \mathrm{cmH} 20$; and a ventilator rate of four assisted mandatory breaths per minute. This implied that the patient made most of the ventilator efforts with very little assistance from the ventilator. Mrs Brown was fully conscious, as sedation was stopped two days before. She was breathing at a spontaneous rate of 18 breaths per minute, and her other vital data remained stable. She stopped wheezing, indicating that the bronchospasms were absent. Her air entry remained clear with good air entry on all four aspects of her lung field, including apexes and bases. Her chest X-ray revealed no signs of a pneumothorax or atelectasis. Negative inspiratory force measurements of above -40 cmH20, together with a good cough reflex, indicated a dramatic improvement in her respiratory status, and that she could be disconnected from the ventilator in order to commence spontaneous breathing.

However, besides this dramatic improvement in the physical health status of the patient, it was still impossible for the doctors and nurses to wean the patient from the ventilator. After several efforts to wean the patient from the ventilator, the patient crushed. Two days before the doctors and nurses had even considered crush extubating the patient. When they tried this, it was necessary for them to reintubate the patient after an hour, as she suddenly developed an acute attack of bronchospasm, which did not respond to corticosteroids and bronchodilator therapy, and she presented with deterioration in her arterial blood gases.

On day 8, Nurse Andreas, who is also a critical care trained nurse with a diploma in Critical Care Nursing Science, was allocated to nurse Mrs Brown. Nurse Andreas described that on this particular morning, after handover and while she was assessing Mrs Brown's health status, she noticed an underlying anxiety in the patient that was revealed in her beautiful brown eyes. [It is appealing to note the amount of compassion with which she describes this experience.] Nurse Andreas also said that, as the patient was still intubated, communication between herself and the patient was based on short sentences that the patient wrote on a piece of paper given to her. She also remarked that throughout this experience with the patient, she kept on wondering why, out of the numerous patients with asthmatic attacks that she had nursed in the past, one out of them responded in such a different way to weaning from mechanical ventilation. I know from experience that patients 
who are ventilated for long periods sometimes develop a dependency on the ventilator, but it is, however, important to consider all the factors that could possibly cause this problem.

Nurse Andreas said “... you know at that moment on that morning, I just knew that this patient was ready to be crushed extubated... and that I also knew that it is the right decision..." After telling the rest of the team, including Dr Blom, who was a bit sceptical, as they had tried this five days previously and it didn't work, Dr Blom consented that I could crush extubate Mrs Brown. After I informed Mrs Brown about this decision, she seemed quite thrilled by it; and I planned to commence the crush extubation of Mrs Brown."

“... You know at $14 \mathrm{~h} 00$, after I had crushed extubated Mrs Brown, I could not find any data that might have indicated that she was developing respiratory difficulty. And an arterial blood gas measurement I obtained 30 minutes after the crush extubation on oxygen that was administered at 8 litres flow, via a 40\% face-mask to Mrs Brown read as follows: $\mathrm{pH}$ of 7.39 ; $\mathrm{Pao} 2$ of $85,5 \mathrm{mmHg}$; $\mathrm{Paco} 2$ of $38 \mathrm{mmHg}$; base excess of $2,2 \mathrm{mmol} / \mathrm{L}$; Bicarbonate (HCO3) of 22,5 moll/L and an oxygen saturation of 95\%. Dr Blom's response to this was that he still wondered how I knew that crush extubation of the patient at that moment was the correct solution to a problem that they had struggled with for almost eight days. On the contrary, Mrs Brown was discharged to a general ward the next day."

From the narrative description, it appears that the nurse in ICU makes clinical decisions that he/she can justify, and others that he/she cannot justify. Therefore, it may be argued that nurses in ICU make clinical decisions in two distinctive ways.

On the one hand, it seems that clinical decisionmaking by the nurse in ICU, for example the decision about the intubation and mechanical ventilation of the patient, is made exclusively on the basis of directly observable and objectively measurable data. The nurse in ICU has gathered this data from an analysis of the health status of the critically ill patient that he/she objectively measured by means of a multitude of monitoring devices attached to the body of the critically ill patient. This way of clinical decision-making by the nurse in ICU corresponds with a scientific-rational way of decision-making (compare Harbison, 1991:404/5). Within a scientific-rational way of decision-making, clinical decisions must be made exclusively on the basis of directly measurable and empirically observable data. The nurse in ICU cannot consider data, for example values and emotions that are not directly measurable during clinical decisionmaking. Furthermore, clinical decisions by the nurse in ICU within a scientific-rational way of decision-making must be rationally justified based on universal rules and principles (compare Baker, 1997:42). A scientific-rational way of clinical decision-making therefore accords with a modernistic (positivistic) scientific view, which is highly regarded in ICU and still dominates the way in which clinical decision-making occurs in ICU.

On the other hand, clinical decision-making in ICU, based on a scientific-rational way of decisionmaking, is relatively simple and has restrictions. These restrictions concern a holistic view of the critically ill patient as a bio-psychosocial being, functioning within an internal and external environment that is constantly interacting with each other. Therefore, a holistic perspective on the critically ill patient implies that both data from the internal and external environments of the critically ill patient should be taken into account during clinical decision-making. This means that both directly and indirectly measurable and observable data, for example emotions and values, must be included during clinical decision-making. Therefore, it seems that clinical decision-making from a holistic perspective on the critically ill patient is much more complicated. 
The nurse in ICU is accountable for his/her clinical decisions, and because the life of the critically ill patient in ICU is at stake during clinical decisionmaking, the nurse in ICU must be able to justify his/her decisions. Justification has to do with reasonableness and, by implication, refers to the justification of clinical decisions by the nurse in ICU by means of argumentation. Therefore, it may be argued that the justification of clinical decisionmaking by the nurse in ICU implies not only a justification of clinical decisions, based on directly measurable and empirically observable data, but also the justification of clinical decisions by means of negotiation and consensus through discourse between the members of the multidisciplinary health team in ICU.

In addition to clinical decisions that need to be justified, it further appears from the narrative that there are clinical decisions that the ICU nurse cannot justify. These clinical decisions are sometimes referred to as "gut-feelings" or intuition (compare Benner \& Tanner, 1987:23). It further seems from the literature that clinical decisions, based on intuition, are effective and contribute to better, more complete problem solving in ICU.

From this problem and argument it appears that the following question is important in this article, namely:

What is the role of intuition in clinical decisionmaking by the nurse in ICU?

\section{PURPOSE OF THE ARTICLE}

The purpose of this article is to debate the role of intuition in clinical decision-making by the nurse in ICU.

\section{THE ROLE OF INTUITION IN CLINICAL DECISION-MAKING}

In order to debate the role of intuition in clinical

Figure 1: Intuition in clinical decision-making by the nurse in ICU

\section{INTENSIVE CARE UNIT (ICU)}

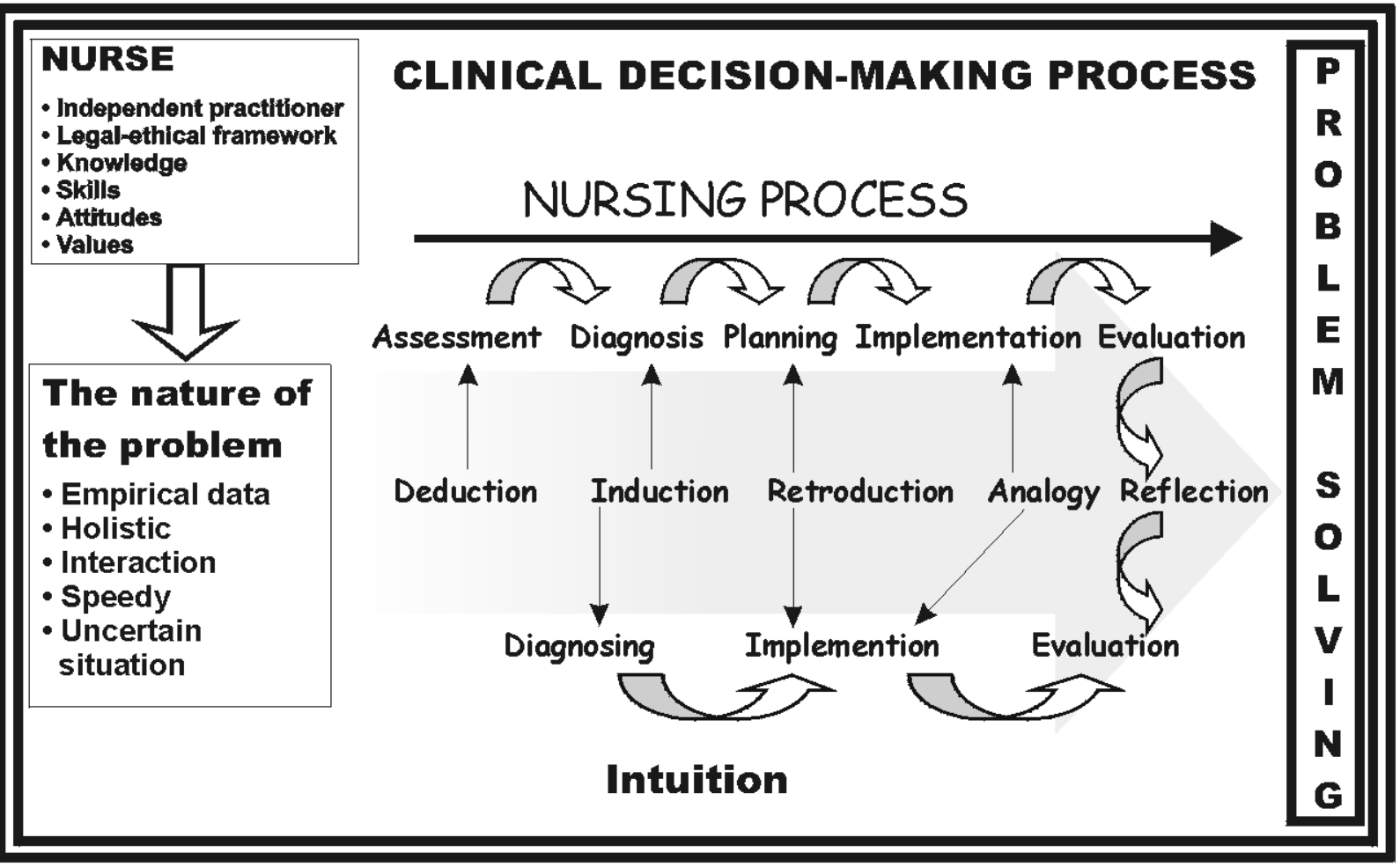


decision-making by the ICU nurse, I would like to draw the reader's attention to figure 1.1.

The debate on the role of intuition in clinical decision-making will be based on the central concepts within figure 1.1. The debate will proceed as follows: firstly, an explication will be given of the nature of the problem with which the critically ill patient presents in ICU. Secondly, the nurse, as an independent practitioner during clinical decision-making in ICU, will be discussed. Thirdly, clinical decision-making as it occurs both during scientific-rational decision-making and intuition will be discussed. Lastly, I shall conclude with some statements on the role of intuition in clinical decision-making and make some recommendations based on this discussion.

\section{The nature of the problem}

The nature of the problem with which the critically ill patient presents determines the way in which the ICU nurse solves it. The nature of the health problem reflects on the critically ill nature of the patient as a biological, psychosocial being. Based on a literature study, it appears that health problems with which critically ill patients in ICU present have certain common dimensions (compare figure 1.1). The first dimension deals with clinical decisions that have been based on empirically observable and directly measurable data, for example, laboratory results of serum and electrolytes, and several other data that is measured by means of a multitude of monitoring devices attached to the body of the critically ill patient (compare Jacobs \& Pelfrey, 1995:46; Bryan \& McIntosh, 1996:27-28).

Secondly, from a holistic perspective on the critically ill patient, the identification and the solving of health problems in the critically ill patient must be viewed holistically. This implies that both data from the internal and external environments of the critically ill patient, as a holistic being, must be considered by the nurse in ICU during clinical decision-making. Therefore, the nurse should take into account both data that is empirically observable and directly measurable on the one hand, and data that is not directly measurable on the other during clinical decision-making.

The third dimension is that the problems diagnosed by the nurse in ICU in the critically ill patient must be solved within a limited time frame in order to prevent complications from developing in the health status of the critically ill patient. Taylor (1997:330), for instance, mentioned that problems with which the critically ill patient in ICU presents must be solved quickly (compare Ellis, 1997:325). This implies that a reduction and systematic analysis of the health status of the critically ill patient is sometimes not feasible, because there is sometimes, metaphorically stated, a race between life and death in ICU, in order to save the life of a critically ill patient.

According to the fourth dimension, clinical decision-making by the ICU nurse is sometimes accompanied with a great deal of uncertainty. This uncertainty stems from incomplete data with which the critically ill patient presents and in itself further contributes to an uncertainty in the clinical decisionmaking situation (compare Shin, 1998:415; Cioffi \& Markham, 1997:267; Jacobs \& Pelfrey, 1995:4849; Miers, 1990:32-33). The critically ill patient, as a holistic human being in ICU, presents mostly with a myriad of data. Some of this data can be objectively measured and is empirically observable, whilst other data, for example the values and emotions of the patient, is indirectly measurable. This incompleteness of data, with which the critically ill patient in ICU presents, leads to a difficult situation where the diagnosing and solving of these problems are very complex (compare Kendrick \& Cubbin, 1996:157; Söderberg \& Norberg, 1993:2008). However, in order to solve problems in ICU completely and effectively, it is important to consider both directly and indirectly measurable data. 
Lastly, the fifth dimension of the problem with which the critically ill patient presents as a holistic human being reflects on the interrelatedness and interaction between the aforementioned dimensions of the problem. This implies that all of these dimensions can be present at the same time during clinical decision-making in ICU.

\section{The nurse in ICU}

The nurse in ICU is an independent practitioner whose practice is endorsed by the Nursing Act (Government notice, Nursing Act, Act number 50 of 1978, as amended). As an independent practitioner, the nurse in ICU works in collaboration with the multidisciplinary team in ICU, within a legal-ethical framework, in order to promote the health of the critically ill patient (Botes, 1994:6366). This legal-ethical framework provides guidance to the nurse in ICU during clinical decision-making. As an independent practitioner, the ICU nurse is responsible and accountable for his/her decisions. Accountability implies that the nurse should be able to justify his/her clinical decisions. The responsibilities and accountabilities of the nurse in ICU are respectively spelled out in the practice regulation (Government Notice, Regulation 2598 of 30 November 1984, as amended) and the regulation about acts and omissions regulations (Government Notice, Regulation 387 of 15 February 1985, as amended). For the nurse to be accountable for his/her clinical decisions implies that he/she must be able to justify his/her decisions based on knowledge, skills and values congruent with the legal-ethical framework of nursing practice in the country.

\section{CLINICAL DECISION-MAKING}

The four phases of the nursing process, namely, assessment, planning, implementation and evaluation describe how clinical decision-making occurs by the nurse in ICU.

\section{Assessment}

During this phase of clinical decision-making, the nurse in ICU assesses the health status of the critically ill patient, based on knowledge and experience through the application of thinking skills such as analysis. Through analysis and deductive logic, the nurse in ICU gathers data from the multitude of monitoring devices attached to the body of the critically ill patient, medical records, laboratory and diagnostic test results, in order to diagnose a health problem.

\section{Assessment during intuition}

Employing intuition, the nurse in ICU also carries out an assessment of the health status of the critically ill patient. However, this assessment takes place without the use of conscious reasoning processes. Using intuition, the nurse in ICU gets "an intuitive grasp of the situation" (Benner, 1982 in English, 1993:390). Based on a perceptual awareness that singles out relevant information from irrelevant information, the nurse in ICU recognises patterns (Benner \& Tanner, 1987:24; Cioffi, 1997:205) in the clinical situation, based on previous experience and knowledge. During this phase, the nurse in ICU also recognises fuzzy resemblance, despite marked differences in the objective data of the current situation (compare Benner \& Tanner, 1987:24; Lauri, Salantera, Callister, Harrison, Kappeli \& Leod, 1998:134).

\section{Diagnosing}

During the diagnostic phase of clinical decisionmaking, the nurse identifies the commonalties from the data collected in the assessment phase. These common features lead to the synthesis of related data that reveal the existence of a health problem in the critically ill patient, through the contemplation of the current data amongst existing scientific knowledge. Through the application of reasoning skills such as synthesis and inductive 
logic, the nurse in ICU diagnoses the existence of a health problem and establishes the need for some nursing or medical intervention in order to solve the problem (compare Thelan, Davie, Urden \& Lough, 1993:7).

\section{Diagnosing during intuition}

Intuitive diagnosis takes place simultaneously with the assessment of the critically ill patient's health status by the ICU nurse. Based on synthesis rather than analysis (compare Miller \& Rew, 1989:85), the nurse in ICU gets an immediate sense of what is wrong with the patient. This is based on a perceptual awareness (compare Benner \& Tanner, 1987) that begins with a vague "hunch" or "gutfeeling" and a global assessment that initially bypasses critical analysis (Benner, 1984 in English, 1993:390). During this perceptual awareness, the nurse singles out relevant information from irrelevant information (Cioffi, 1997:205), recognises relationships (pattern recognition) between data without pre-specifying the components of the situation and recognises similarities, despite marked differences in the objective features of past and present situations (Benner \& Tanner, 1987:24). Awareness that a patient reminds the nurse of a similar patient raises new questions and possibilities. Based on a deep understanding of the situation at a meta-cognitive level and empathy, the nurse develops a common sense understanding of what is wrong with the critically ill patient (compare Benner \& Tanner, 1987:25). Linking together data about the health status of the critically ill patient and the situation at a meta-cognitive level, based on previous knowledge and past experience, the nurse in ICU arrives at a solution for the problem with which the critically ill patient presents.

\section{Planning}

Once the nursing diagnosis is established, the planning component of the clinical decision-making process begins. Through retroductive argumentation, which implies a logical inference about the best possible explanation for the observable events, the nurse plans what the best possible solution would be for the diagnosed problem. This also entails the assignment of priorities to the nursing diagnosis, specifying the intermediate and long-term goals through the interpretation of the nursing diagnosis, and deciding on specific nursing actions to be implemented, in order to attain these goals (compare McCarthy, 1981:175; Alfaro-LeFevre, 1994:127).

\section{Planning during intuition}

Intuitive planning occurs simultaneously with the previous two phases, namely, assessment and diagnosis. The ICU nurse is often able to leap directly into implementation, as planning, based on knowledge and previous experience, has become automatic (Casebeer in Marquis \& Huston, 1994:910; Hampton, 1994:16). Therefore, it may be inferred that problems intuitively diagnosed are solved much faster, because of the speed at which diagnosis occurred. The speed at which intuitive decision-making occurs has to do with its bypassing of the so-called rational thinking processes at an unconscious level (Isaack, 1978:919; Rew, 1986:23; Mitchell, 1994:2).

\section{Implementation}

Implementation refers to the carrying out of the proposed plan of nursing actions. Nursing actions are co-ordinated by the nurse so that the planned activities facilitate solving of the health problem to promote the health of the critically ill patient. The nurse also draws an analogy between the current clinical decision-making situation and similar clinical decisions he/she has made in the past, by looking for similarities. These actions might include technical clinical procedures, such as intubation and initiating mechanical ventilation, the manipulation of an intra-aortic-balloon pump, 
pulmonary arterial catheter, a ventilator or inotropic support, or consulting with other members of the multidisciplinary health team in ICU, in order to solve the health problems with which the critically ill patient has presented (Nel, 1993:74-76; AlfaroLeFevre, 1994:180).

\section{Implementation during intuitive decision- making}

This phase proceeds in a similar way as during the nursing process. Benner (1982), however, is of the opinion that clinical decisions based on intuition made by the expert ICU nurse can be observed when he/she demonstrates them in action only. According to Schraeder and Fisher (1986:161-162) the nurse in ICU is empowered during intuition to come into direct contact with a solution for a problem that he/she has encountered in the clinical situation based on knowledge and experience (compare Corcoran, 1986:107-112; Cioffi, 1997:203-208; Ellis, 1997:325-332). When the nurse in ICU is asked to justify his/her actions, he/she is unable to do so, as the so-called rational thinking processes are bypassed. Therefore Benner and Tanner (1987:23) refer to intuition as knowing without a rationale. The nurse can only justify his/her actions after the decision is made and some authors such as Benner and Tanner (1987:26) refer to this as "deliberative rationality".

\section{Evaluation}

Evaluation refers to a critical analytic process whereby the nurse assesses the patient's response to the nursing actions that have been implemented and to what extent goals have been achieved, based on certain criteria formulated during the planning phase. The nurse also evaluates the effectiveness of his/her decisions in order to justify them through the application of reflective and logical thinking skills (McCarthy, 1981:176; Swansburg, 1993:182; Alfaro-LeFevre, 1994:206).

\section{Evaluation during intuitive decision-making}

During intuitive decision-making the nurse also carries out an evaluation after the decision has been made. This implies that the nurse must be able to reflect in order to be able to arrive at an understanding of the nature of the problem, the process implemented and how he/she arrived at the solution. In this way the nurse in ICU develops a deep understanding of the process and the outcome of clinical decisions based on intuition, develops a changed and new perspective about his/her clinical decision-making and justifies them (compare Clarke, James \& Kelly, 1996:172; Greenwood, 1993:1185; Schön, 1987:70), It is, therefore, imperative for the nurse to be able to develop reflective thinking skills.

\section{CONCLUSION}

I shall now proceed to draw a conclusion from the aforementioned arguments on the role of intuition in clinical decision-making by the nurse in ICU.

From the aforementioned arguments, it clearly seems that the nature of the problem with which the critically ill patient presents in ICU is a critical determinant of the way the problem will be solved. It further appears that, should only a scientificrational way of clinical decision-making be employed in ICU, with its central requirements of clinical decision-making, based only on directly observable and objectively measurable data, then certain dimensions of the health problem with which the critically ill patient might present cannot be addressed. It may therefore be argued that the solving of health problems in the critically ill patient will be incomplete. The dimensions of the health problems that seem not to be addressed during clinical decision-making in ICU deal with a holistic perspective of the critically ill patient in ICU. From a holistic perspective on the critically ill patient, data that cannot be directly measured during clinical decision-making by the ICU nurse, for instance 
values and emotions, also form part of the health problem with which a critically ill patient presents. To demonstrate this, the reader's attention is drawn back to the narrative. It seems from the narrative that the problem that the doctors and nurses in ICU encountered during the weaning of the mechanical ventilation of the patient have to do with their failure to consider data such as the critically ill patient's ability to take responsibility for his/her illness. By Nurse Andreas taking data, such as the internal motivation of Mrs Brown to survive, into consideration, she seemed to have found a solution for a problem that the rest of the health team in ICU had been struggling with for almost a week.

In order to prevent deterioration in the health status of the critically ill patient in ICU, clinical decisions by the nurse in ICU must sometimes be made within a limited time frame. A scientific, rational approach with its emphasis on the carrying out of a systematic analysis of the health status of the critically ill patient and the clinical decision-making situation all at once seems not to provide a suitable solution to this dimension of the problem. Taking into consideration the critically ill nature of the patient in ICU and carrying out a systematic analysis of the health status of the patient are time consuming. Any delay in solving problems with which the critically ill patient might present, might potentially be detrimental to the health of the patient and may even cause his/her death, especially if a problem must be solved quickly and effectively. It seems that intuition, as a way of clinical decision-making, accommodates this dimension of the problem. Intuition is a speedy process during clinical decision-making, which is based on knowledge, perceptual awareness, empathy and experience of similar problems that the ICU nurse has encountered in the past, enabling him/her to focus directly on the myriad of data with which the critically ill patient presents, in order to find a solution to the problem. The speed at which intuitive decision-making occurs is made possible as so-called rational thinking processes are bypassed (compare Rew, 1986:23; Isaack, 1978:919). Furthermore, it seems from the literature and experience in clinical decisionmaking in ICU, that these clinical decisions, which are based on intuition, are effective (compare Cioffi, 1997:203-208; Mitchell, 1994:2-3; Doering, 1992:23-33; Benner \& Wrubal, 1982:11-17).

The critically ill patient in ICU presents with a myriad of directly and indirectly measurable data most of the time. This as well as the unavailability of directly measurable data lead to great uncertainty in ICU. Therefore, the nurse in ICU must sometimes make clinical decisions based on incomplete data in uncertain situations (compare Schraeder \& Fischer, 1986:161). Again it seems that intuition provides an answer to this dimension of the nature of the problem. Intuitive decisionmaking occurs mostly when clinical decisions must be made based on incomplete data in uncertain situations (Tversky \& Kahnemann, 1973:207-232; Tversky \& Kahnemann, 1974:1124-1131; Kehoe, 1997:46-47; Orme \& Maggs, 1993:270-276; Benner \& Tanner, 1987:23-31; Benner, 1982:402407).

I therefore conclude this debate by stating that without intuition during clinical decision-making, certain problems in ICU cannot be solved. In order to achieve better, more complete problem solving in ICU, clinical decisions, both based on a scientific-rational way of clinical decision-making, as it is for example, applied in the nursing process, and on intuition are necessary.

\section{RECOMMENDATIONS}

I now conclude with some recommendations to clinical practice and nursing education.

The nurse in ICU is responsible and accountable to justify his/her clinical decisions. This counts for clinical decisions, both based on a scientificrational way and on intuition. However, clinical decisions based on intuition can be justified after 
the problem has been solved only, and that will require the nurse to reflect. Therefore, reflective thinking skills seem to be a crucial requirement to be able to justify both clinical decisions based on intuition and those based on a scientific-rational way of decision-making. Reflective thinking skill refers to a cyclic, hierarchic and interactive construction process. This is initiated, extended and continued because of personal cognitiveaffective interaction (individual dimension) as well as interaction with the social environment (social dimension) (Van Vuuren \& Botes, 1999:33). I therefore plead with nurse educators to facilitate this ability in the nursing student during their training and education. Through the use of narratives, reflective journals and case studies, these reflective thinking abilities could be facilitated in the nursing student.

In addition to reflective thinking skills, the facilitation of knowledge together with experience seems to be crucial in order to be able to make clinical decisions based on intuition. In this way clinical decisions based on intuition will be distinguished from those of trial-and-error. Trialand-error problem solving requires that the nurse in ICU attempt several different approaches until a solution is found for a problem (Taylor, 1997:329). This method is not efficient and is dangerous in ICU, as it might lead to deleterious outcomes in the health status of the critically ill patient. However, intuition is based on knowledge, which through experience becomes densely interwoven within the knowledge framework of the expert nurse (Jasper, 1994:771). It is therefore recommended that, through methods such as continuous education and in-service education, the knowledge of the nurse in ICU be extended and advanced in order to improve clinical decision-making abilities.

Besides reflective thinking ability, knowledge and experience, the nurse should also be able to demonstrate empathy in the clinical decisionmaking situation. The distinctive characteristics of empathy, according to Wiseman (1996:1165), are to see the world from the perspective of someone else, to understand the emotions of other people, to have an unbiased view of other people, and to communicate understanding of the world of other people (compare Botes, 1997:12). Therefore, in order to truly experience the world of the critically ill patient, nurses in ICU (and possibly others as well) must be able to demonstrate empathy. Through the demonstration of empathy in the clinical decision-making situation, the nurse in ICU will be able to develop a common sense understanding of the patient and of what is really wrong with him/her, helping the nurse to better diagnose and solve problems in ICU more completely and effectively.

I therefore conclude that, in order to consider the role of intuition in clinical decision-making in ICU, the development of reflective thinking ability, combined with knowledge, experience and empathy, should form part of the nursing education system in the country.

\section{BIBLIOGRAPHY}

ALFARO-LEFEVRE, R 1994: Applying Nursing Process: A step-by-step guide; third edition. Philadelphia: JB Lippincot Company.

ARRIES, EJ; BOTES, AC \& NEL, WE 1998: Intuïsie in kliniese besluitneming deur die verpleegkundige in intensiewesorgeenhede. Johannesburg: Randse Afrikaanse Universiteit. Magister-skripsie.

ARRIES, E; BOTES, A \& NEL, E 1999: Konsepanalise van intuïsie. Curationis, Sept. 1999

BAKER, JD 1997: Phenomenography: An alternative approach to researching the clinical decision-making of nurses. Nursing Inquiry, 4, 1997:41-47.

BENNER, P \& TANNER, C 1987: Clinical judgement: How expert nurses use intuition. American Journal of 
Nursing, 87(1), 1987:23-31.

BENNER, P \& WRUBAL, J 1982: Skilled clinical knowledge: The value of perceptual awareness. Nurse Educator. May-June 1982:11-17.

BENNER, P 1982: From novice to expert. American Journal of Nursing, March 1982:402-407.

BENNER, P 1984: From novice to expert: Excellence and power in clinical nursing practice. California: Addison-Wesley

BOTES, AC 1994: ' $n$ Model vir etiese besluitneming in verpleging. Curationis, 17(4), Desember 1994:66-70.

BOTES, AC 1997: Die etiek van omgee en die etiek van geregtigheid in etiese besluitneming in die gesondheidspan. Johannesburg: Randse Afrikaanse Universiteit (Professorale intree-rede).

BRYANS, A \& MCINTOSH, J 1996: Decision-making in community nursing: An analysis of the stages of decision-making as they relate to community nursing assessment practice. Journal of Advanced Nursing, 24, 1996:24-30.

CIOFFI, J 1997: Heuristics, servants to intuition in clinical decision-making. Journal of Advanced Nursing, 26, 1997:203-208.

CIOFFI, J \& MARKHAM, R 1997: Clinical decisionmaking by midwives: Managing case complexity. Journal of Advanced Nursing, 25, 1997:265-272.

CLARKE, B; JAMES, C \& KELLY, J 1996: Reflective practice: Reviewing the issues and refocusing the debate. International Journal of Nursing Studies, 33(2), 1996:171-180.

CORCORAN, SA 1986: Task complexity and nursing expertise as factors in decision-making. Nursing Research, 35(2), March/April 1986:107-112.
DOERING, L 1992: Power and knowledge in nursing: A feminist post-structuralistic view. Advanced Nursing Science, 14(4), 1992:23-33.

ELLIS, PA 1997: Processes used by nurses to make decisions in the clinical practice setting. Nurse Education Today, 17, 1997: 325-332.

ENGLISH, I 1993: Intuition as a function of the expert nurse: A critique of Benner's novice to expert model. Journal of Advanced Nursing, 18, 1993:387-393.

GREENWOOD, J 1993: Reflective practice: A critique of the work of Argyris and Schön. Journal of Advanced Nursing, 1993:1183-1187.

HAMPTON, DC 1994: Expertise: The true essence of nursing art. Advanced Nursing Science, 17(1), 1994:15-24.

HARBISON, J 1991: Clinical decision-making in nursing. Journal of Advanced Nursing, 16, 1991:404407.

ISAACK, TA 1978: Intuition: An ignored dimension of management. Academy of Management Review, 3, 1978:917-922.

JACOBS, SM \& PELFREY, S 1995: Decision support systems: Using computers to help manage. Journal of Nursing Administration, 25(2), February 1995:46-51

JASPER, MA 1994: Expert: A discussion of the implications of the concept as used in nursing. Journal of Advanced Nursing, 20, 1994:769-776.

KEHOE, J 1997: Mind power into the 21st Century. Canada: Zoetic Inc.

KENDRICK, K \& CUBBIN, B 1996: Ethics in the intensive care unit: A need for research. Nursing Ethics, 3(2), 1996:157-164.

LAURI, S; SALANTERA, S; CALLISTER, LC; 
HARRISON, S; KAPPELI, S \& LEOD, MM, 1998: Decision making of nurses practicing in intensive care in Canada, Finland, Northern Ireland, Switzerland and the United States. Heart \& Lung, March/April; Volume 27, Number 2.

MARQUIS, BL \& HUSTON, CJ 1994: Management decision-making for nurses; second edition. Philadelphia: JB Lippincott.

MCCARTHY, MM 1981: The nursing process: Application of current thinking in clinical problem solving. Journal of Advanced Nursing, 6, 1981:173177.

MIERS, M 1990: Developing skills in decision-making. Nursing Times, 25, 85(30), 1990:32-33.

MILLER, VG \& REW, L 1989: Analysis and intuition: The need for both in nursing education. Journal of Nursing Education, 28(2), 1989:84-87.

MITCHELL, GJ 1994: Intuitive knowing: Exposing a myth in theory development. Nursing Science

Quarterly, 7(1), 1994:2-3.

NEL, WE 1993: Die funksies van die intensiewe verpleegkundige in die Republiek van Suid-Afrika. Johannesburg: Randse Afrikaanse Universiteit (D.Curproefskrif).

ORME, L \& MAGGS, C 1993: Decision-making in clinical practice: How do expert nurses, midwives and health visitors make decisions? Nurse Education Today, 13, 1993:270-276.

REW, L 1986: Intuition: A concept analysis of a group phenomenon. Advances in Nursing Science, 8(2), 1986:21-28.

SCHöN, D 1987: Educating the Reflective Practitioner. San Francisco: Jossey-Bass Publishers.

SCHRAEDER, B \& FISHER, D 1986: Using intuitive knowledge in the neonatal intensive care nursery. Holistic
Nursing Practice, 1(3), 1987:45-51.

SHIN, KR 1998: Critical thinking ability and clinical decision-making skills among senior nursing students in associate and baccalaureate programs in Korea. Journal of Advanced Nursing, 27, 1998:414-418.

SöDERBERG, A \& NORBERG, A 1993: Intensive care: Situations of ethical difficulty. Journal of Advanced Nursing, 18, 1993:2008-2014.

SUID-AFRIKAANSE (REPUBLIEK): Wet op Verpleging soos gewysig deur Wet no. 21 van 1992 (Wet no. 50 van 1978). Pretoria: Staatsdrukker.

SUID-AFRIKAANSE RAAD OP VERPLEGING 1984: Regulasies betreffende die praktyk van persone wat kragtens die Wet op Verpleging, 1978 geregistreer of ingeskryf is. R2598. Pretoria: Suid-Afrikaanse Raad op Verpleging.

SUID-AFRIKAANSE RAAD OP VERPLEGING 1985: Regulasies betreffende die Handelinge en Versuime van persone wat kragtens die Wet op Verpleging, 1978 geregistreer of ingeskryf is. R387. Pretoria: Suid Afrikaanse Raad op Verpleging.

SWANSBURG, RC 1993: Introductory management and leadership for clinical nurses: A textbook. Boston: Jones and Barlett Publishers.

TAYLOR, C 1997: Problem-solving in clinical nursing practice. Journal of Advanced Nursing, 26, 1997:329336.

THELAN, LA; DAVIE, JK; URDEN, LD \& LOUGH, ME 1993: Critical Care Nursing: Diagnoses and Management; second edition. St Louis Missouri: Mosby Company.

TVERSKY, A \& KAHNEMANN, D 1973: Availability: A heuristic for judging frequency and probability. Cognitive Psychology, 5, 1973:207-232. 
TVERSKY, A \& KAHNEMANN, D 1974: Judgement

under uncertainty: Heuristic and biases. Science, 185, 1974:1124-1131.

VAN VUUREN, M \& BOTES, AC 1999: Konsepanalise van reflektiewe denke. Curationis, September, 25-

35.

WISEMAN, T 1996: A conceptual analysis of empathy. Journal of Advanced Nursing, 23, 1996:1162-1167. 